\title{
ofROTASIO
}

Available online at Website http://ejournal.undip.ac.id/index.php/rotasi

\section{PENGARUH CU TERHADAP REAKSI ANTARMUKA BAJA DAN ALUMINIUM DENGAN PERLAKUAN DIFUSI}

\author{
*Mathius Karengke ${ }^{\mathrm{a}}$, Triyono ${ }^{\mathrm{b}}$, Agus Supriyanto $^{\mathrm{c}}$ \\ ${ }^{a}$ Mahasiswa Program Magister Teknik Mesin Universitas Sebelas Maret \\ ${ }^{\mathrm{b} J u r u s a n}$ Teknik Mesin, Fakultas Teknik, Universitas Sebelas Maret \\ ${ }^{\mathrm{c} J u r u s a n}$ Fisika, Fakultas MIPA, Universitas Sebelas Maret Surakarta \\ Jl. Ir. Sutami 36 A Kentingan Surakarta 57126 \\ *Email: mathiuskarengke@yahoo.com, triyonomesin@uns.ac.id
}

\begin{abstract}
Nowadays, developing vehicle is made as light as posible with the purpose to reduce energy consumption. For this reason, material that can be used is aluminium that has light weight and non corrosion properties. Aluminum structure will be not strong enough, it still need another material like steel to make it stronger and stiffer. Joining aluminum to steel has problems because of very low solubility, thus it requires other material as its medium in which it accelerates promoter solubility aluminum to steel. In this study, mixture of $\mathrm{Fe}$ and $\mathrm{Cu}$ powder was used as promoter material or filler in the process of diffusion welding of aluminium and steel.. The good results diffusion between the steel with aluminum filler hence the need for variation of $\mathrm{Fe}$ and $\mathrm{Cu}$. Aluminum and steel welding process with adapting diffusion treatment will produces intermetallic layer. Intermetallic layer was formed from the fussion among two different material, and it made new compound. This research showed some different solubility level of aluminum in steel in every variation of filler composition. The highest solubility ratio of aluminum in steel was 0.4 which reached in the specimens with filler composition of $40 \% \mathrm{Fe}, 60 \% \mathrm{Cu}$ and $60 \% \mathrm{Fe}, 40 \% \mathrm{Cu}$.
\end{abstract}

Keywords: aluminum, diffusion, filler composition, intermetallic, steel

\section{PENDAHULUAN}

Kendaraan yang banyak dikembangkan saat ini adalah membuatnya semakin ringan, dengan tujuan menghemat energi. Michael dan Maaz [1] mengatakan produksi kendaraan ringan dunia mencapai 83,3 juta. Hal ini memerlukan banyak material logam untuk membuat struktur kendaraan tersebut. Material alternatif dapat digunakan yaitu aluminium karena memiliki sifat tahan karat dan ringan. Kendaraan yang menggunakan struktur aluminium secara keseluruhan tidak cukup, tetapi membutuhkan material lain seperti baja dalam pembentukannya.

Permasalahan yang sering ditemukan dalam penyambungan aluminium dengan baja adalah sambungan tersebut menghasilkan lapisan intermetalik. Hasil penelitian yang sama menunjukkan bahwa baja dengan aluminium yang disambung akan menghasilkan lapisan intermetalik yang rapuh pada temperatur tinggi [2]. Lapisan intermetalik terbentuk oleh dua unsur yang menyatu dan membentuk senyawa baru. Aluminium terlarut ke baja sangat rendah sehingga sangat sulit dilakukan penyambungan. Hal tersebut disebabkan unsur pembentuk material tidak sama, sehingga memerlukan material lain sebagai media perantara. Penelitian Kobayashi dan Yakao [3] menyatakan bahwa lapisan intermetalik dapat dikendalikan oleh perlakuan difusi.

Lapisan intermetalik dapat dikendalikan dengan perlakuan difusi, oleh sebab itu pengembangan ke arah penelitian tersebut banyak dilakukan. Seperti penelitian yang menggabungkan aluminium paduan ke baja dengan efek fusi oleh Chen dan Kovacevic [4], kemudian oleh Zhao dan Zhang [5] menggunakan difusi untuk mendapatkan kekuatan yang lebih tinggi pada sambungan $\mathrm{Al}$ dan $\mathrm{Mg}$. Penelitian Mahendra dan Senthil [6] dengan penyambungan difusi Mg/Al.

Perkembangan pengelasan logam tidak sejenis memacu juga pengelasan dengan metode lain seperti resistance spot welding yang diteliti oleh Sun dan Khalel [7]. Kimapong dan Watanabe [8] meneliti pengelasan plat paduan aluminium ke baja ringan menggunakan las gesekan aduk (FSW) dengan kecepatan rotasi dan diameter pin. Sun, dkk [9] meneliti pengelasan resistance spot welding pada paduan aluminium dengan baja menggunakan transisi pada kedua material. Takehiko, dkk [10] meneliti pengelasan paduan aluminium dan baja dengan friction stir welding (FSW). Qiu, dkk [11] meneliti mikrostruktur dan kekuatan baja dengan aluminium pada pengelasan resistance spot welding menggunakan plat penutup. Penelitian ini bertujuan untuk mengetahui pengaruh $\mathrm{Cu}$ terhadap reaksi antarmuka baja dan aluminium dengan perlakuan difusi.

\section{MATERIAL DAN METODOLOGI}

\subsection{Material}

Material yang digunakan dalam pengelasan difusi ini yaitu aluminium 6061 tebal $6 \mathrm{~mm}$ dan SS 400 tebal 2,3 $\mathrm{mm}$. Material tersebut dipotong 30x30 mm, pada bagian tengah dibuat diameter $20 \mathrm{~mm}$ dengan kedalaman $1 \mathrm{~mm}$. 
Tabel 1. Komposisi Kimia Al 6061 dan SS 400

\begin{tabular}{ccccccccccc}
\hline Material & $\mathrm{Mg}$ & $\mathrm{Si}$ & $\mathrm{Fe}$ & $\mathrm{Mn}$ & $\mathrm{Cu}$ & $\mathrm{Cr}$ & $\mathrm{Zn}$ & $\mathrm{Ni}$ & $\mathrm{Ti}$ & $\mathrm{Al}$ \\
\hline $\mathrm{Al} 6061$ & 0,95 & 0,54 & 0,22 & 0,13 & 0,17 & 0,09 & 0,08 & 0,02 & 0,01 & bal \\
\hline \multicolumn{10}{c}{ Sumber : Dinaharan, dkk. [12] } \\
\hline Material & $\mathrm{C}$ & $\mathrm{Mn}$ & $\mathrm{Si}$ & $\mathrm{P}$ & $\mathrm{Cr}$ & $\mathrm{Mo}$ & $\mathrm{Ni}$ & $\mathrm{Cu}$ & $\mathrm{Fe}$ \\
\hline SS 400 & 0,05 & 0,225 & 0,15 & 0,094 & 0,04 & 0,05 & 0,07 & 0,16 & bal \\
\hline \multicolumn{10}{c}{ Sumber :Triyono, dkk. [13] }
\end{tabular}

Tabel 2. Sifat Mekanik Al 6061 dan SS 400

\begin{tabular}{cccccc}
\hline Material & $\begin{array}{c}\text { Melting Point } \\
\left({ }^{\circ} \mathrm{C}\right)\end{array}$ & $\begin{array}{c}\text { Specific } \\
\text { Heat }\left(\mathrm{J} / \mathrm{kg} .{ }^{\circ} \mathrm{C}\right)\end{array}$ & $\begin{array}{c}\text { Density } \\
\left(\mathrm{kg} / \mathrm{m}^{3}\right)\end{array}$ & $\begin{array}{c}\text { Thermal Conductivity } \\
\left(\mathrm{J} / \mathrm{m}^{3} .{ }^{\circ} \mathrm{C} . \mathrm{s}\right)\end{array}$ & $\begin{array}{c}\text { Electrical Resistivity } \\
(\mu \Omega . \mathrm{cm})\end{array}$ \\
\hline Al 6061 & 660 & 900 & 2700 & 220 & 2,65 \\
\hline \multicolumn{7}{c}{ Sumber: Aizawa, dkk. $[14]$} \\
Material & $\begin{array}{c}\text { Melting Point } \\
\left({ }^{\circ} \mathrm{C}\right)\end{array}$ & $\begin{array}{c}\text { Thermal } \\
\text { Conductivity } \\
(\mathrm{W} / \mathrm{mK})\end{array}$ & $\begin{array}{c}\text { Coefficient of Thermal } \\
\text { Expansion }\left(\mu \mathrm{m} / \mathrm{m} /{ }^{\circ} \mathrm{C}\right)\end{array}$ & $\begin{array}{c}\text { Tensile } \\
\text { Strenght } \\
(\mathrm{Mpa})\end{array}$ & $\begin{array}{c}\text { Electrical Resistivity } \\
(\mu \Omega . \mathrm{cm})\end{array}$ \\
\hline SS 400 & $1495-1525$ & 12,6 & 13,0 & 240 & 2,65 \\
\hline
\end{tabular}

Sumber :Triyono, dkk. [13]

\subsection{Komposisi Filler}

Komposisi filler dari penelitian ini yaitu $\mathrm{Fe} 10 \%, \mathrm{Cu} 90 \%$; $\mathrm{Fe} 20 \%, \mathrm{Cu} 80 \%$; $\mathrm{Fe} 40 \%, \mathrm{Cu} 60 \%$; $\mathrm{Fe} 50 \%, \mathrm{Cu}$ $50 \%$; Fe 60\%, Cu 40\%; Fe $70 \%$, Cu $30 \%$; Fe 80\%, Cu $20 \%$ dan tanpa filler

\subsection{Proses Pengelasan}

Lokasi penelitian pada laboratorium material Jurusan Teknik Mesin, Universitas Sebelas Maret Surakarta. Pengelasan difusi aluminium dengan baja dalam prosesnya berada dalam ruang hampa menggunakan furnace. Pada kondisi seperti ini, pengelasan difusi dapat terjadi dengan baik. Proses difusi ini terjadi pada dua permukaan material yang berbeda antara Al 6061 dengan SS 400. Hal ini bertujuaan agar atom kedua material saling terdifusi sehingga terjadi ikatan kuat antaramuka material yang disambung. Tabel 1 memperlihatkan komposisi kimia $\mathrm{Fe}$ dan $\mathrm{Cu}$ pada material Al 6061 dan SS 400. Hal ini yang mendasari sehingga menggunakan variasi komposisi filler Fe dan $\mathrm{Cu}$. Tabel 2 memperlihatkan tahanan listrik yang sama pada Al 6061 dan SS 400 yaitu sebasar 2,65 $\mu \Omega . c m$. Kesamaan ini juga merupakan suatu kelebihan yang dimiliki oleh kedua material sehingga dapat dilakukan penyambungan difusi.

Material tersebut dipotong dengan ukuran 30 x $30 \mathrm{~mm}$, kemudian pada bagian plat SS 400 dibuat lingkaran di tengah sebesar $20 \mathrm{~mm}$ dengan kedalaman $1 \mathrm{~mm}$. Pada bagian tengah diberikan komposisi serbuk, lalu dimasukkan dalam furnice sampai temperatur $950^{\circ} \mathrm{C}$ dan ditahan selama 30 menit.
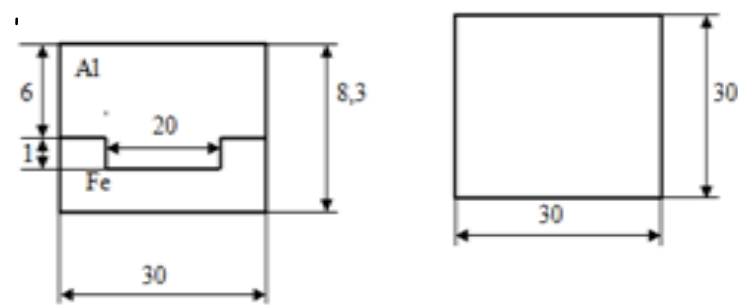

Gambar 1. Spesimen ukuran dalam mm.

Gambar 1 spesimen dipotong keempat sisinya untuk melihat berapa besar kelarutan antarmuka Al 6061 dengan SS400 menggunakan filler dengan komposisi yang bervariasi.

Tabel 3. Komposisi filler dengan temperatur dan holding time konstan

\begin{tabular}{ccccc}
\hline NO & \multicolumn{2}{c}{ Variasi Filler } & Temperatur & Holding Time \\
\hline 1. & $\mathrm{Fe} 10 \%$ & $\mathrm{Cu} 90 \%$ & $950{ }^{\circ} \mathrm{C}$ & 30 menit \\
\hline 2. & $\mathrm{Fe} 20 \%$ & $\mathrm{Cu} 80 \%$ & $950{ }^{\circ} \mathrm{C}$ & 30 menit \\
\hline 3. & $\mathrm{Fe} 40 \%$ & $\mathrm{Cu} 60 \%$ & $950{ }^{\circ} \mathrm{C}$ & 30 menit \\
\hline 4. & $\mathrm{Fe} 50 \%$ & $\mathrm{Cu} 50 \%$ & $950{ }^{\circ} \mathrm{C}$ & 30 menit \\
\hline 5. & $\mathrm{Fe} 60 \%$ & $\mathrm{Cu} 40 \%$ & $950{ }^{\circ} \mathrm{C}$ & 30 menit \\
\hline 6. & $\mathrm{Fe} 70 \%$ & $\mathrm{Cu} 30 \%$ & $950{ }^{\circ} \mathrm{C}$ & 30 menit \\
\hline 7. & $\mathrm{Fe} 80 \%$ & $\mathrm{Cu} 20 \%$ & $950{ }^{\circ} \mathrm{C}$ & 30 menit \\
\hline
\end{tabular}




\subsection{Pengujian}

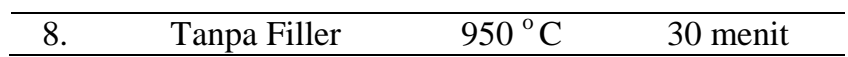

Penelitian menggunakan foto makro, mikro, dan pengujian SEM (EDX) sehingga struktur mikro dari sambungan tersebut dapat diketahui secara lengkap.

\section{HASIL DAN PEMBAHASAN}

Tabel 3 terdapat variasi $\mathrm{Fe}$ dan $\mathrm{Cu}$ yang dikembangkan untuk mendapatkan hasil yang optimal pada pengelasan difusi. Penelitian ini difokuskan pada hasil difusi material Al 6061 dengan SS 400 yang diperoleh dari pengembangan variasi komposisi filler $\mathrm{Fe}$ dan $\mathrm{Cu}$. Pada setiap spesimen terjadi difusi antara kedua permukaan material yang berbeda. Hal tersebut mengakibatkan aluminium dengan baja saling mengikat.

\subsection{Foto Makro}

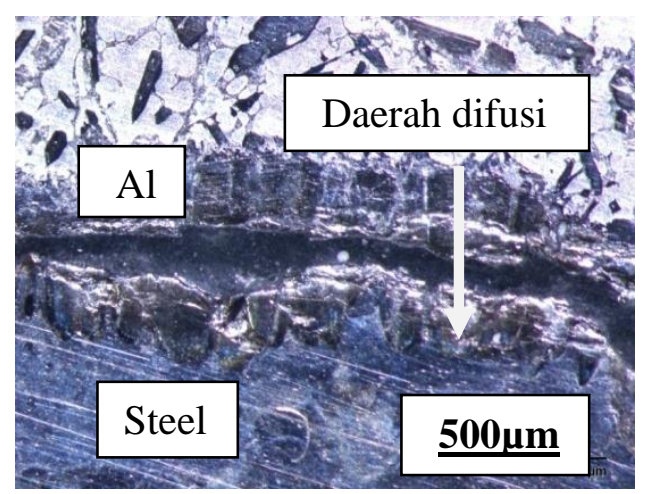

Gambar 2. Fe $10 \%, \mathrm{Cu} 90 \%$

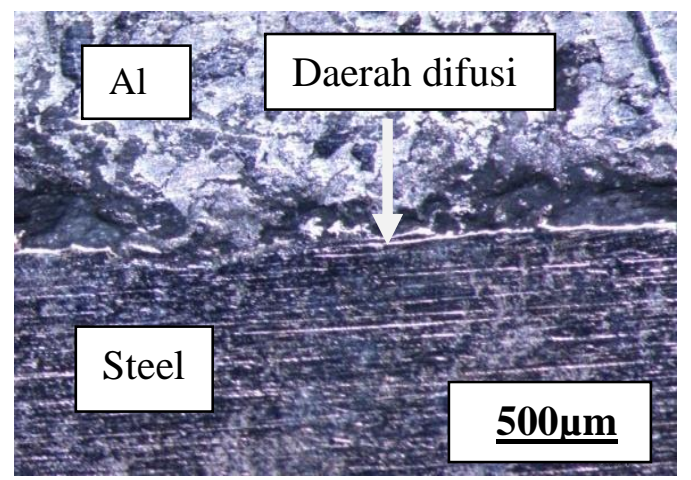

Gambar 3. Fe $20 \%, \mathrm{Cu} 80 \%$

Gambar 2 terlihat daerah permukaan antara aluminium dan baja terjadi difusi. Gambar 3 terdapat daerah difusi yang mengakibatkan permukan keduanya saling menyatu. Hal ini tampak sangat jelas pada Gambar 12 foto mikro, aluminium terlarut ke dalam baja.

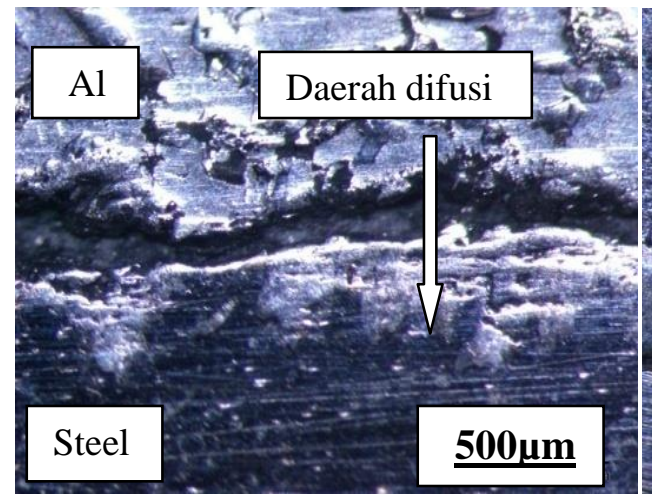

Gambar 4. Fe $80 \%, \mathrm{Cu} 20 \%$

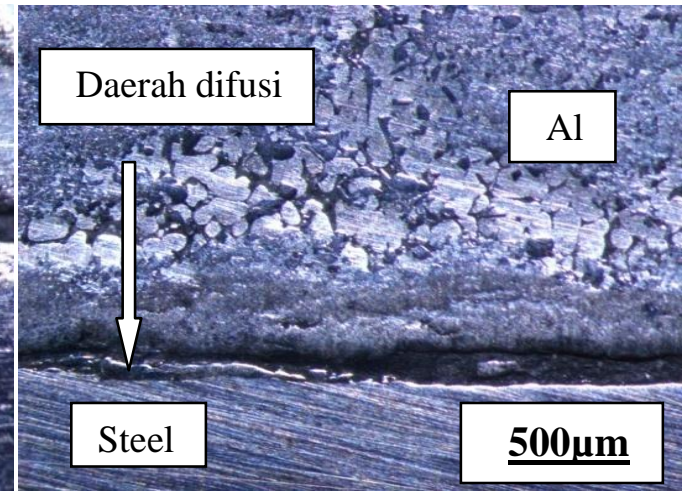

Gambar 5. Fe 70\%, Cu 30\%

Gambar 4 dan 5 terlihat permukaan terdifusi dengan komposisi filler yang berbeda memperlihatkan bahwa terjadi kelarutan aluminium ke dalam baja seperti yang tampak Gambar 12 dan17 pada foto mikro.
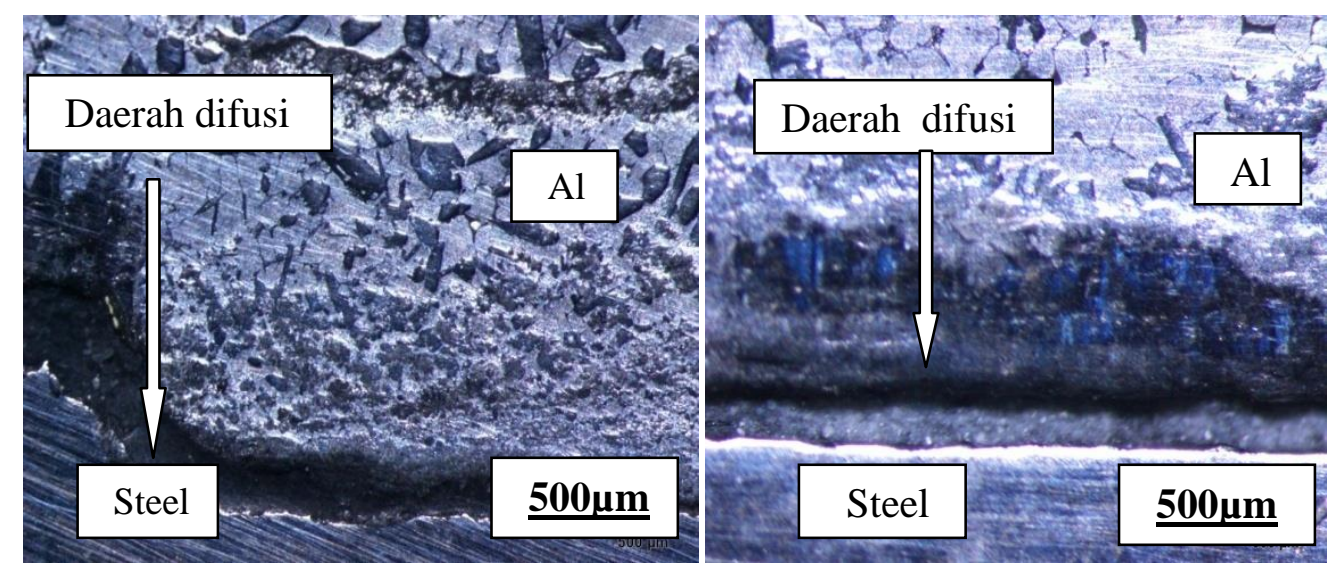
Gambar 6. Fe 60\%, $\mathrm{Cu} 40 \%$

Gambar 7. $\mathrm{Fe} 40 \%, \mathrm{Cu} 60 \%$

Gambar 6 memperlihatkan bahwa dengan komposisi Fe $60 \%, \mathrm{Cu} 40 \%$ terjadi retak anatarmuka, sehingga ikatan antarmuka kedua material tidak cukup baik. Hal tersebut mengakibatkan permukaan kedua material tidak saling menyatu. Gambar 7 terlihat daerah terdifusi di permukaan sehingga pada komposisi ini terjadi kelarutan antara aluminium dengan baja yang menyebabkan mengikatnya kedua material tersebut.

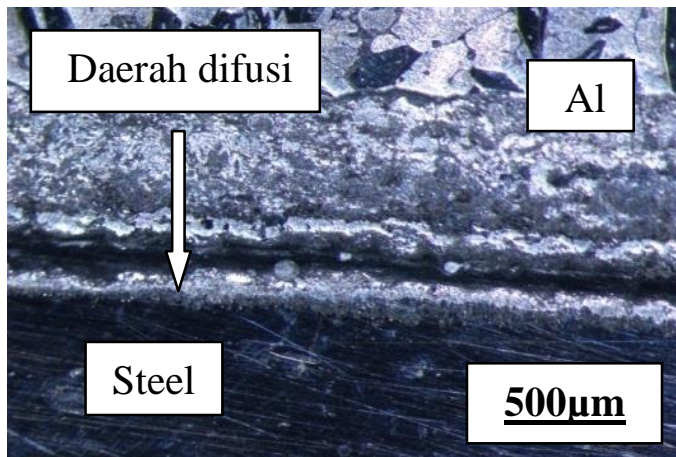

Gambar 8. Fe 50\%, Cu 50\%

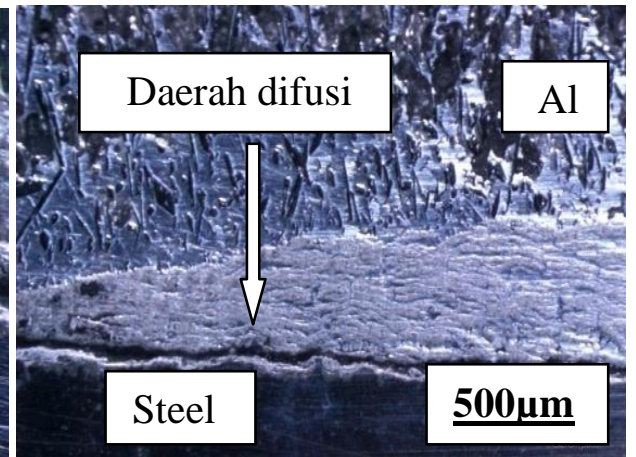

Gambar 9. Tanpa filler

Gambar 8 dan 9 terlihat daerah difusi pada permukaan yang menandakan terlarutnya aluminium ke baja sehingga saling mengikat seperti yang terlihat pada Gambar foto mikro 15 dan 18.

\subsection{Foto Mikro}

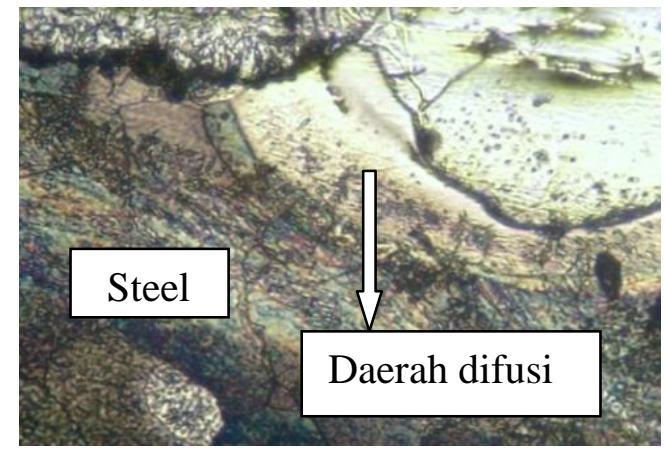

Gambar 10. $\mathrm{Fe} 10 \%, \mathrm{Cu} 90 \%$

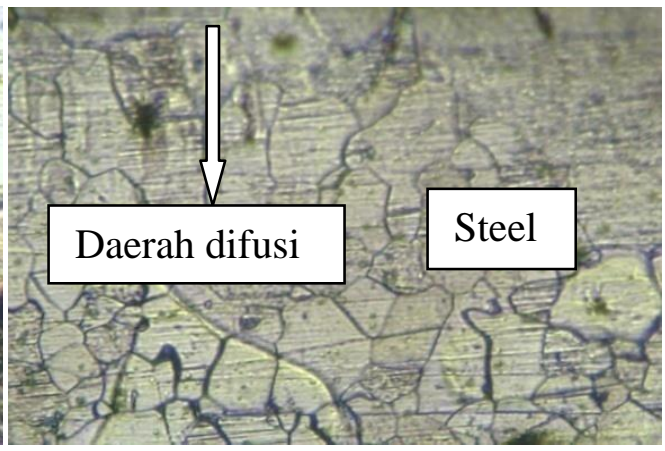

Gambar 11. Fe $20 \%$, Cu $80 \%$

Gambar 10 memperlihatkan terjadinya daerah difusi yang mengakibatkan kelarutan aluminium di daerah baja. Komposisi layer Fe $10 \%, \mathrm{Cu} 90 \%$ pada ikatan difusi yang diperlihatkan dengan SEM EDX adanya fusi antarmuka mengakibatkan 37,56 wt \% aluminium yang dapat terlarut di antarmuka baja, sehingga terjadi ikatan antarmuka kedua material. Pengaruh unsur Fe (05,11 wt \%), C(34,31 wt \%), O (16,16 wt \%), Cu (03,06 wt \%) serta Mg (03,80 wt \%). Al masih sangat dominan di antarmuka, sehingga baja tidak cukup terlarut dengan aluminium. Gambar 11 memperlihatkan di antarmuka baja terdapat aluminium (8,47 wt \%), Fe (73,80 wt \%), C (9,39 wt \%), O (7,58 wt \%), Mg (0,76 wt \%) . Pertambahan jumlah Fe di permukaan aluminium mengakibatkan ikatan antara baja dan aluminium akan semakin baik.

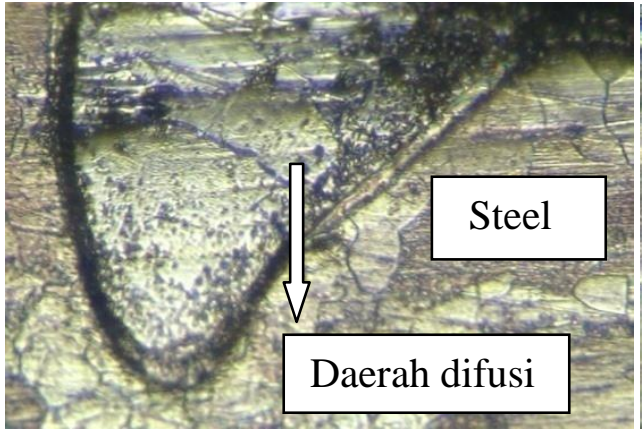

Gambar 12. $\mathrm{Fe} 40 \%, \mathrm{Cu} 60 \%$

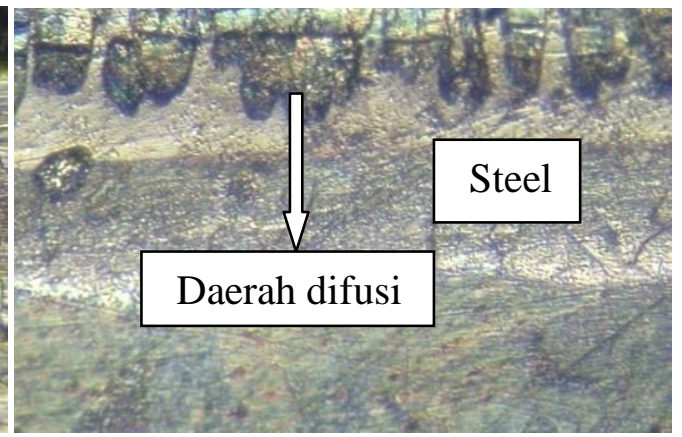

Gambar 13. $\mathrm{Fe} 50 \%, \mathrm{Cu} 50 \%$

Gambar 12 memperlihatkan daerah difusi aluminium yang tergradasi di daerah baja, hal tersebut menunjukkan bahwa komposisi layer Fe 40\%, Cu $60 \%$ dapat terjadi difusi di antarmuka. Hasil SEM EDX terdapat unsur Al (23,97 
wt \%), Fe (59,71 wt \%), O (5,17 wt \%), C (11, 15wt \%). Banyaknya atom aluminium yang terlarut dengan baja menunjukkan bahwa komposisi layer ini membuat kedua material terdifusi. Gambar 13 memperlihatkan komposisi layer $\mathrm{Fe} 50 \%, \mathrm{Cu} 50 \%$ memperlihatkan daerah difusi di sepanjang permukaan baja dengan unsur $\mathrm{Al}(4,32 \mathrm{wt} \%)$, Fe (74,83 wt \%), O (3,31 wt \%), C (17,11 wt \%), Cu (0,43 wt \%). Komposisi layer ini terdapat unsur aluminium yang terlarut ke baja terjadi penurunan yang cukup besar, sehingga mengurangi homogenitas kedua material tersebut.

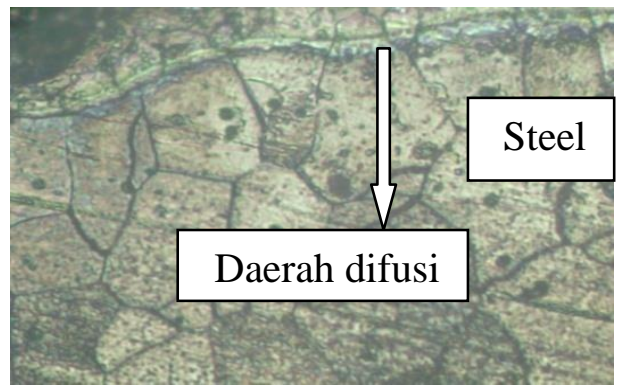

Gambar 14. $\mathrm{Fe} 60 \%, \mathrm{Cu} 40 \%$

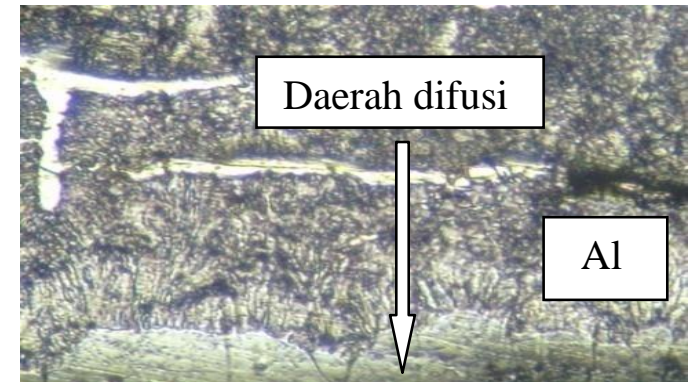

Gambar 15. $\mathrm{Fe} 70 \%, \mathrm{Cu} 30 \%$

Gambar 14 memperlihatkan daerah difusi yang mengakibatkan kelarutan aluminium ke baja. Komposisi layer Fe $60 \%, \mathrm{Cu} 40 \%$ diperlihatkan dengan SEM EDX unsur Al cukup banyak jumlahnya sehingga ikatan antarmuka kedua material baik. Jumlah unsur aluminium $(34,41 \mathrm{wt} \%)$ yang dapat terlarut di antarmuka baja. Unsur C(41,96 wt \%), $\mathrm{O}$ (9,14 wt \%), serta Fe (10,51 wt \%) serta $\mathrm{Cu}(1,41$ wt \%). Gambar 15 memperlihatkan komposis Fe 70\%, Cu 30\% pada permukaan aluminium terdapat Fe (70,10 wt \%), C (12,35 wt \%), O (2,56 wt \%), Mg (0,40 wt \%), Cu (1,53 wt \%) serta Al $(13,05$ wt \%). Pertambahan jumlah Fe di antarmuka mengakibatkan ikatan antara baja dan aluminium akan semakin baik.

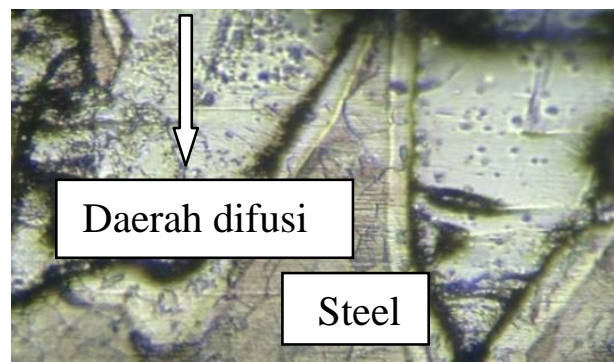

Gambar 16. Fe $80 \%, \mathrm{Cu} 20 \%$

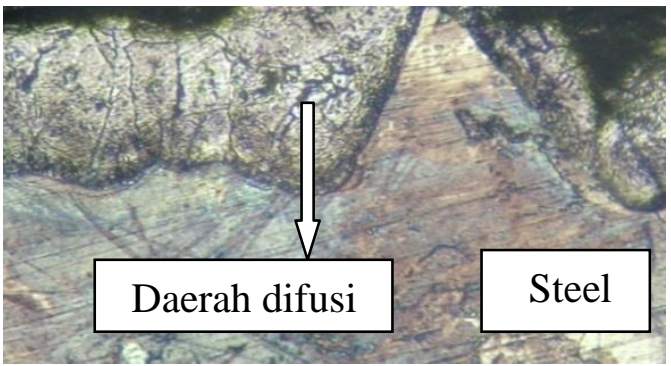

Gambar 17. Tanpa filler

Gambar 16 memperlihatkan daerah difusi aluminium yang terlarut dengan baja, hal ini menunjukkan bahwa pada komposisi layer Fe 80\%, $\mathrm{Cu} 20 \%$ dapat terjadi fusi di antarmuka. Hasil SEM EDX terdapat unsur Al (49,97 wt \%), Fe (9,15 wt \%), C (20,45 wt \%), O (12,90 wt \%), Mg (6,86 wt \%), serta $\mathrm{Cu}(0,68 \mathrm{wt} \%)$. Atom aluminium terlihat dapat terlarut dengan baja, menunjukkan adanya ikatan difusi. Komposisi layer merupakan promotor sehingga terjadi fusi antarmuka yang berdampak terhadap kedua material. Gambar 17 memperlihatkan daerah difusi disepanjang antarmuka baja dengan unsur $\mathrm{Al}(24,00 \mathrm{wt} \%), \mathrm{Fe}(69,15 \mathrm{wt} \%), \mathrm{C}(6,84 \mathrm{wt} \%)$. Besarnya unsur aluminium yang tergradasi ke baja menunjukkan homogenitas kedua material pada temperatur $950^{\circ} \mathrm{C}$, fasa yang terbentuk austenit.

\subsection{SEM EDX}
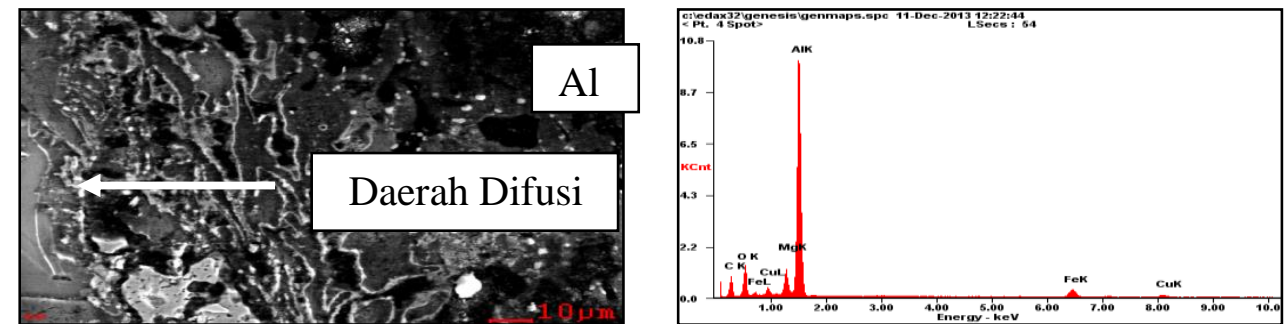

Gambar 18. SEM EDX komposisi filler Fe 10\%, $\mathrm{Cu} 90 \%$

Gambar 18 terlihat kelarutan antara Fe dengan Al, terjadi daerah fusi antarmuka. Atom Fe terlarut ke aluminium sehingga membentuk homogenitas kedua material tersebut. Penguataan presipitasi yang terjadi akibat munculnya fasa baru berupa senyawa antar logam. Fe yang terlarut di permukaan sebesar 5,11 wt \% mengakibatkan terjadinya ikatan antarmuka baja dan aluminium membentuk lapisan intermetalik $\mathrm{Fe}_{7} \mathrm{Al}$. 


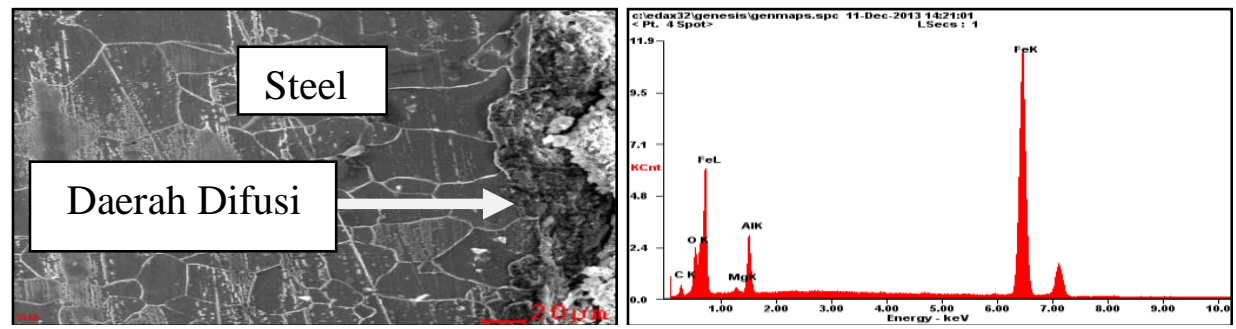

Gambar 19. SEM EDX komposisi filler $\mathrm{Fe} 20 \%$, Cu $80 \%$

Gambar 19 memperlihatkan bahwa keterlarutan antara Al ke Fe sebesar 8,47 wt \%. Material membentuk lapisan yang homogenitas di antarmuka, sehingga terjadi fusi kedua material tersebut dan membentuk lapisan intermetalik. Unsur yang terbentuk di antarmuka adalah lapisan intermetalik $\mathrm{FeAl}_{9}$.
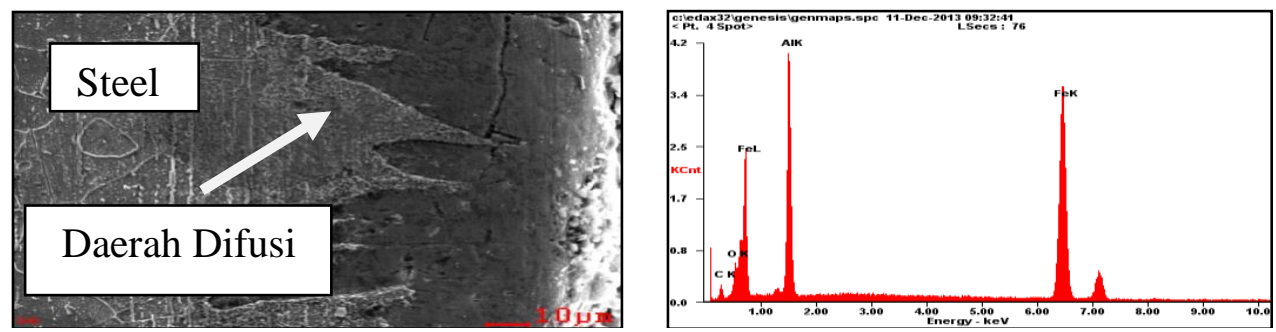

Gambar 20. SEM EDX komposisi filler $\mathrm{Fe} 40 \%, \mathrm{Cu} 60 \%$

Gambar 20 terjadi peningkatan unsur Al sebesar 23, 97 wt \% ke Fe dibandingkan dengan gambar 19. Hal ini menyebabkan kelarutan kedua unsur dengan tingkat homogenitas semakin baik. Al terdifusi ke Fe sehingga mengikat kedua unsur tersebut dan membentuk senyawa baru. Senyawa baru terbentuk di antarmuka yang sifatnya sangat keras. Senyawa baru terbentuk dari perpaduan $\mathrm{Fe}$ dan $\mathrm{Al}$ di antarmuka material dan membentuk lapisan intermetalik $\mathrm{Fe}_{2}$.
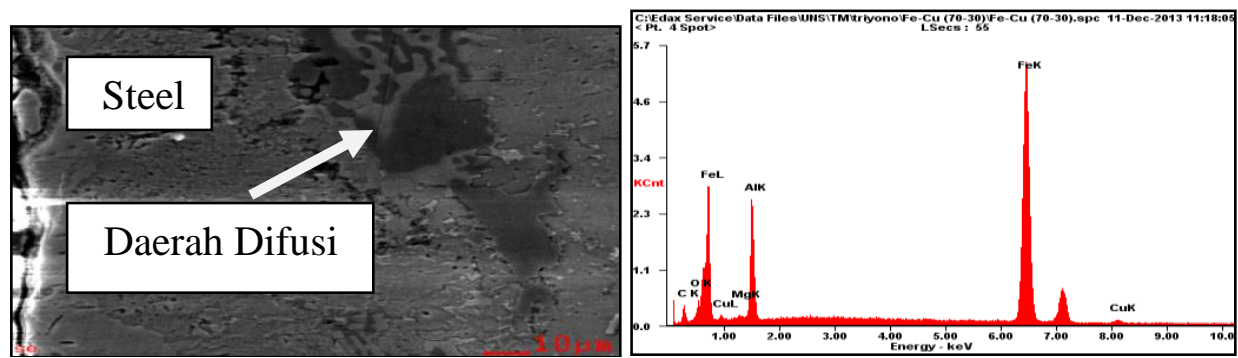

Gambar 21. SEM EDX komposisi filler $\mathrm{Fe} 50 \%, \mathrm{Cu} 50 \%$

Gambar 21 memperlihatkan unsur $\mathrm{Al}$ 4, 32 wt \% terlarut ke Fe menyebabkan kelarutan kedua unsur tersebut membentuk senyawa baru. Aluminium terlarut ke baja pada suhu $950^{\circ} \mathrm{C}$ dengan komposisi layer $\mathrm{Fe} 50 \%, \mathrm{Cu} 50 \%$ membentuk lapisan yang sangat keras. Senyawa yang terbentuk di antarmuka material tersebut membentuk lapisan intermetalik $\mathrm{FeAl}_{18}$ yang sangat keras dan rapuh pada temperatur tinggi.
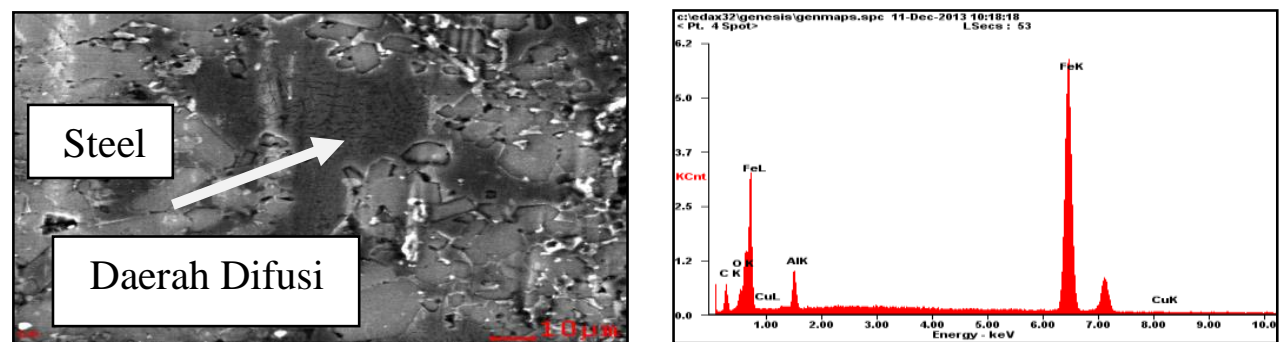

Gambar 22. SEM EDX komposisi filler Fe 60\%, Cu 40\%

Gambar 22 memperlihatkan unsur Al terlarut ke Fe sebesar 34,41 wt \%, dengan fakta tersebut dapat disimpulkan bahwa pada suhu $950^{\circ} \mathrm{C}$ aluminium dalam kondisi liquidus sehingga atom $\mathrm{Fe}$ dapat terlarut secara besar besaran membentuk lapisan homogen. Schimek, dkk [15] menggambarkan dalam diagram fasa $\mathrm{Fe}-\mathrm{Al}$ pada temperatur $950^{\circ} \mathrm{C}$ akan terjadi lapisan intermetalik. Unsur $\mathrm{Al}$ yang terlarut ke baja di permukaan membentuk lapisan intermetalik $\mathrm{Fe}_{3} \mathrm{Al}$. 


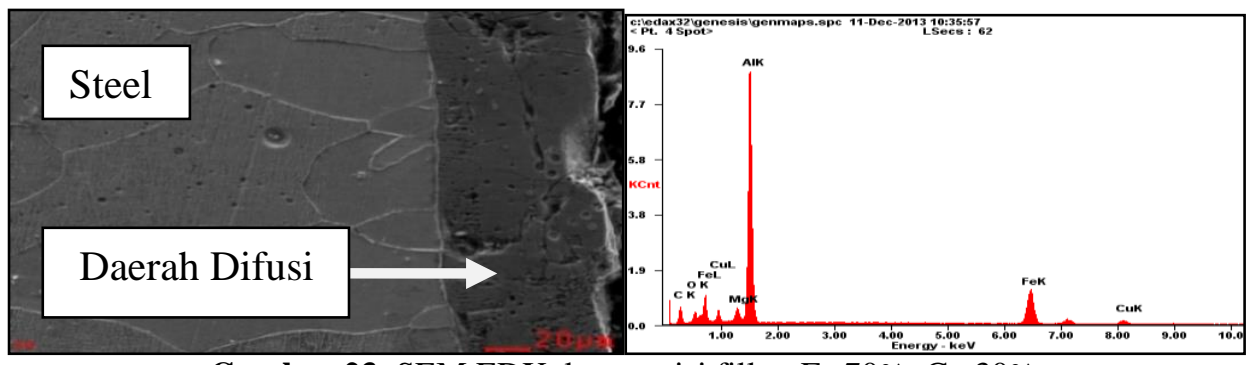

Gambar 23. SEM EDX komposisi filler $\mathrm{Fe} 70 \%$, Cu 30\%

Gambar 23 terdapat unsur Al ke Fe di permukaan sebesar 13, 05 wt \% menyebabkan kelarutan kedua unsur membentuk senyawa intermetalik $\mathrm{FeAl}_{5}$. Lapisan intermetalik dalam penelitian ini tidak dapat dihindari, dikarenakan penggabungan unsur Fe dengan $\mathrm{Al}$ membentuk senyawa baru pada temperatur $950^{\circ} \mathrm{C}$. Filler di permukaan sebagai promotor kedua material sehingga dapat berdifusi dengan baik.
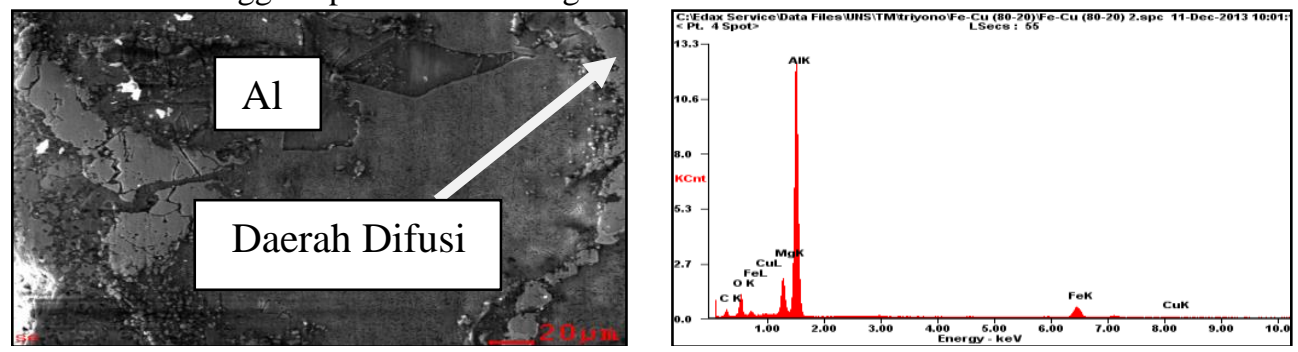

Gambar 24. SEM EDX komposisi filler $\mathrm{Fe} 80 \%, \mathrm{Cu} 20 \%$

Gambar 24 memperlihatkan unsur Al yang terlarut ke Fe sebesar 49,97 wt \%. Al yang terlarut cukup banyak, dan membentuk senyawa intermetalik $\mathrm{Fe}_{5} \mathrm{Al}$.
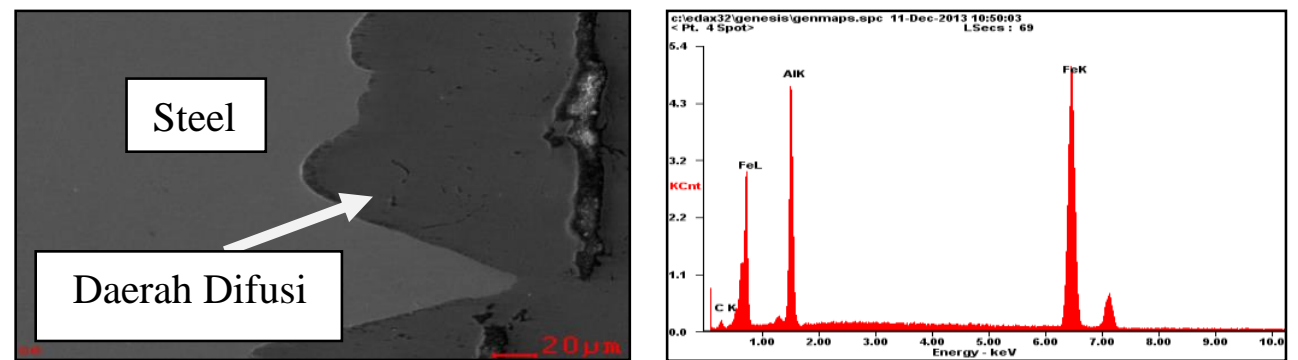

Gambar 25. SEM EDX tanpa filler

Gambar 25 memperlihatkan unsur Al terlarut ke Fe sebesar 24,00 wt \%. Al dalam jumlah yang cukup besar dapat terlarut menunjukkan bahwa tingkat homogenitas $\mathrm{Fe}$ dan $\mathrm{Al}$ pada temperatur $950^{\circ} \mathrm{C}$ sangat baik. Banyaknya unsur Al yang terlarut di antarmuka memiliki pengaruh yang signifikan, tetapi unsur tersebut membentuk lapisan intermetalik di antarmuka material. Senyawa intermetalik yang terbentuk di antarmuka adalah $\mathrm{FeAl}_{3}$. 


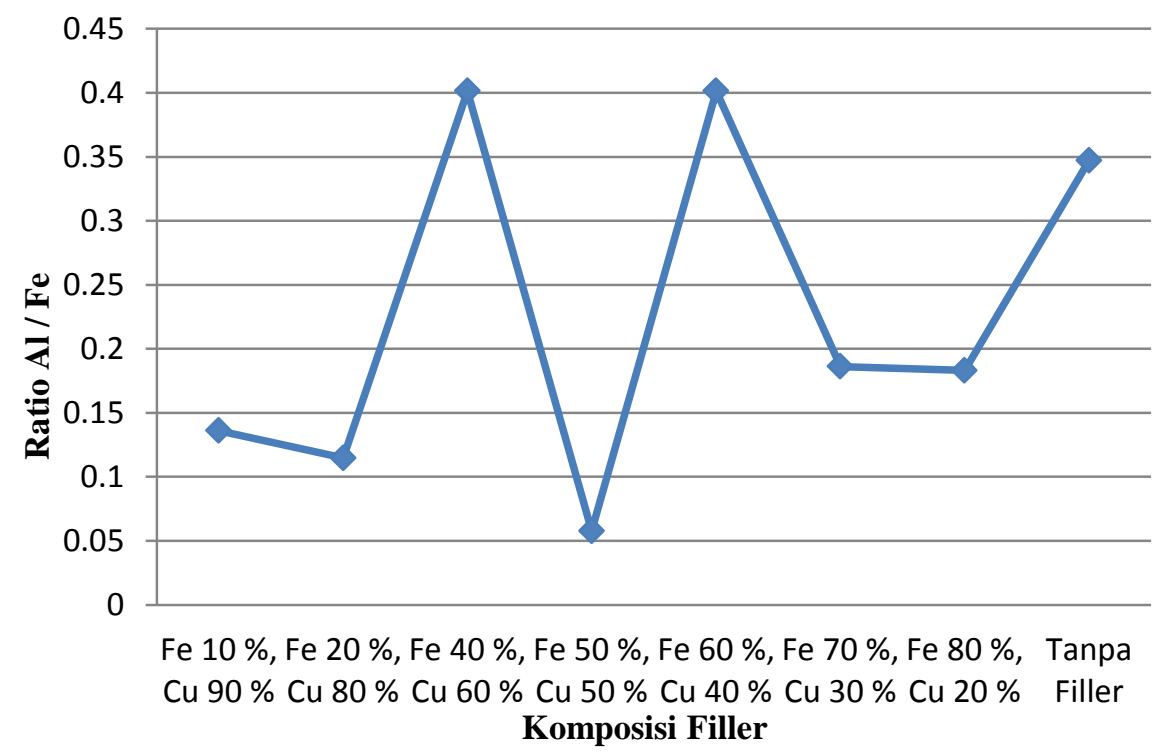

Gambar 26. Grafik Kelarutan $\mathrm{Al}$ ke Fe

Gambar 26 memperlihatkan bahwa ratio kelarutan aluminium ke baja yang tertinggi yaitu 0,4 pada komposisi filler $\mathrm{Fe} 60 \%, \mathrm{Cu} 40 \%$ dan $\mathrm{Fe} 40 \%, \mathrm{Cu} 60 \%$. Hal ini diakibatkan oleh kemampuan filler sebagai promotor dapat membuat kelarutan di antarmukan sehingga terjadinya difusi pada keduan material dapat berjalan dengan baik.

\section{KESIMPULAN}

Hasil yang diperoleh menggunakan filler Fe dan $\mathrm{Cu}$ dapat disimpulkan sebagai berikut :

1) Pada setiap variasi filler dan tanpa filler terjadi difusi aluminium ke baja tetapi memiliki perbedaan tingkat kelarutan.

2) Ratio kelarutan Al ke Fe tertinggi sebesar 0,4.

3) Pengaruh $\mathrm{Fe}$ dan $\mathrm{Cu}$ terhadap kelarutan aluminium ke baja tertinggi pada komposisi filler $\mathrm{Fe} 40 \%, \mathrm{Cu} 60 \%$ dan $\mathrm{Fe}$ $60 \%, \mathrm{Cu} 40 \%$.

\section{REFERENSI}

[1] Michael R dan Maaz G. 2013. Automobile Production Set new Record, but Alternative Grow Slowly. Vital Signs.

[2] Bouche K, Barbier F, dan Coulet A. 1998. Intermetallic Compound Layer Growth Between Solid Iron and Molten Aluminium. Mater. Sci. Eng. A 249,167-175.

[3] Kobayashi S dan Yakou T. 2002. Control of Intermetallic Compound Layers at Interface between Steel and Aluminum by Diffusion-Treatment. Mater. Sci. Eng. A 338, 44-53.

[4] Chen CM dan Kovacevic R. 2004. Joining of Al 6061 alloy to AISI 1018 steel by combined effects of fusion and solid state welding. Machine Tools \& Manufacture. 44 , 1205-1214.

[5] Zhao LM dan Zhang ZD. 2008. Effect of Zn Alloy Interlayer on Interface Microstructure and Srength of Diffusion Bonded Mg-Al Joints. Scripta Mater. 58, 283-6.

[6] Mahendra G, Balasubramanian V, dan Senthilvelant. 2009. Developing Diffusion Bonding Windows for Joint AZ31B Magnesium-AA 2024 Aluminium Alloy. Material and Design.30, 1240-4.

[7] Sun X dan Khalel MA. 2007. Dynamic strength evaluations for self-piercing rivets and resistance spot welds joining similar and dissimilar metals. Impact Engineering .34, 1668-1682.

[8] Kimapong K. dan Watanabe T. 2004. Friction Stir Welding of Aluminum Alloy to Steel. Welding Journal. 277282.

[9] Sun X, Stephens EV, Khaleel AH, Shao, dan Kimchi M. 2004. Resistance Spot Welding of Aluminium Alloy to Steel with Transition Material-From Process to Performance. Welding Journal.188-195.

[10] Takehiko, Watanabe, Hirofumi Takayama, dan Atsushi Yanagisawa. 2006. Joining of aluminum alloy to steel by friction stir welding. Materials Processing Technology. 178, 342-349.

[11] Qiu A, Rafeng, Shinobu S, dan Chihiro I. 2009. Effect of interfacial reaction layer continuity on the tensile strength of resistance spot welded joints between aluminum alloy and steels. Material and Design. 30, 3686-3689.

[12] Dinaharan K, Kalaiselvan, Vijay SJ, dan Raja P. 2012. Effect of Material Location and Tool Ratational Speed on Microstructure and Tensil Strength of Dissimilar Friction Stir Welded Aluminium Alloy. Archives of Civil and Mechanical Engineering. 12, 446-456.

[13] Triyono, Yustiasih P, dan Ikwal C. 2013. Critical Nugget Diameter of Resistance Spot Welded Stiffened Thin Plate Structure. Modern Applied Science. Vol 7,No.7,17-22. 
[14] Aizawa T, Kashani M, dan Okagawa K. 2007. Application of Magnetic Pulse Welding For Aluminium Alloys and SPCC steel sheet Joint. Welding Reasearch. Vol.86,119-124.

[15] Schimek M, Springer A, Kaerle S, Kracht V, dan Wesling. 2012. Laser Welded Dissimilar Steel- Aluminium Seams for Automotive Light Construction. Physics Procedia. 39, 43-50.

\section{UCAPAN TERIMA KASIH}

Penulis mengucapkan terima kasih atas dukungan dana dari Menteri Pendidikan dan Kebudayaan Republik Indonesia melalui hibah MP3EI dengan kontrak No.499/UN. 27.11/PN/2014. 